Karolina Rokicka

Uniwersytet Mikołaja Kopernika, Toruń

\title{
Przepisy i normy otwierające porządek prawny na prawo międzynarodowe i procesy integracyjne w Republice Federalnej Niemiec
}

DOI: http://dx.doi.org/10.12775/SIT.2014.014

\section{Uwagi wstępne, rys historyczny}

Przepisy i normy otwierające wewnętrzny porządek prawny danego państwa na prawo międzynarodowe i procesy integracyjne są podstawą jego udziału w działaniach organizacji lub organu międzynarodowego. Choć problematyka niniejszego artykułu została zakreślona w sposób ogólny, należy podkreślić zasadniczą rolę Unii Europejskiej i jej ogromny wpływ na przemiany, jakie zaszły w konstytucjach państw europejskich w związku ich z przystąpieniem do tej organizacji. Klauzule integracyjne nie bez przyczyny określa się częściej jako klauzule europejskie bądź artykuły europejskie. Prawdopodobnie nie zostanie uznaneza nadużycie stwierdzenie, iż to właśnie Unia Europejska nadaje ton regulacjom konstytucyjnym w zakresie przepisów otwierających porządek prawny. Na potwierdzenie niniejszej tezy wskazać można choćby przepisy konstytucji Estonii (§ 1 ustawy o uzupełnieniu Konstytucji Republiki Estońskiejl)

${ }^{1}$ Ustawa o uzupełnieniu Konstytucji Republiki Estońskiej przyjęta w referendum przeprowadzonym 14 września 2003 roku (RT nr 64 z 10 X 2003, 
czy Słowacji (art. 7 ust. 2 konstytucji Republiki Słowackiej²), wyraźnie wymieniające $z$ nazwy Unię Europejską i odnoszące się do sposobu przyjmowania wprowadzanych przez nią przepisów do danego systemu prawa.

Każde państwo Unii Europejskiej samodzielnie kształtuje normy, na podstawie których następuje otwarcie wewnętrznego porządku prawnego na normy prawa europejskiego. Jednym $z$ problemów związanych $z$ tym procesem jest wprowadzenie do konstytucji opisu (charakterystyki) Unii Europejskiej. Jak wskazuje Maria Kruk, wzorowanie się w tym zakresie na państwach założycielach UE (np. Niemcach bądź Francji) nie jest prawidłowe, gdyż w tych krajach regularne normy dotyczące przynależności do Unii były tworzone stosunkowo późno, tzn. dopiero po traktacie z Maastricht, kiedy integracja polityczna Europy zaczęła nabierać bardziej sformalizowanego charakteru ${ }^{3}$. Być może Ustawa zasadnicza ${ }^{4}$ Republiki Federalnej Niemiecnie stanowi najlepszego wzoru w zakresie uregulowań dotyczących przepisów integracyjnych. Niewątpliwie jest ona jednakże godna przeprowadzenia głębszej analizy.

Gdy w dniu 23 maja 1949 roku uchwalano konstytucję RFN, przypisywano jej przymiot prowizoryczności, nie zakładając, iż będzie obowiązywać ponad pół wieku. Analizując regulacje tego aktu prawnego, należy jednak uwzględniać około 120 tomów zbiorów orzecznictwa Federalnego Sądu Konstytucyjnego (Bundesverfassungsgericht, dalej: FSK) oraz ponad 50 nowelizacji ustawy zasadniczej5.

poz. 429); http://libr.sejm.gov.pl/tek01/txt/konst/estonia2011.html (dostęp: 7 sierpnia 2013 r.).

${ }^{2}$ Konstytucja Republiki Słowackiej z dnia 1 września 1992 r. ze zm., http:// libr.sejm.gov.pl/tek01/txt/konst/slowacja.html (dostęp: 10 sierpnia 2013 r.).

${ }^{3}$ Zob. M. Kruk, Kształtowanie konstytucyjnych zasad członkostwa państwa $w$ Unii Europejskiej (wybrane problemy), „Przegląd Sejmowy”2010, nr 4 (99), s. 43 .

${ }^{4}$ Grundgesetzfürdie Bundesrepublik Deutschland (Ustawa zasadnicza Republiki Federalnej Niemiec) z dnia 23 maja 1949 r. (BGBl. 1949, t. 1, s. 1 ze zm.), dalej: uz.

${ }^{5}$ Por. Ch. Starck, Ustawa Zasadnicza po 60 latach. Niemieckie i europejskie perspektywy, tłum. P. Czarny, „Przegląd Sejmowy” 2009, nr 6 (95), s. 18. 
Republika Federalna Niemiec 18 kwietnia 1951 roku została jednym z państw założycieli Europejskiej Wspólnoty Węgla i Stali, co nastąpiło na podstawie art. 24 ust. $1 \mathrm{uz}$, będącego nośnikiem pierwotnej klauzuli integracyjnej, stanowiącej nowość w ówczesnym konstytucjonalizmie światowym ${ }^{6}$. Również współtworzenie przez Niemcy Europejskiej Wspólnoty Gospodarczej oraz Europejskiej Wspólnoty Energii Atomowej 25 marca 1957 roku, a także podpisanie każdego kolejnego traktatu rewizyjnego następowało na podstawie upoważnienia zawartego $\mathrm{w}$ art. $24 \mathrm{uz}^{7}$.

Do 24 grudnia 1992 roku $^{8}$ art. 23 alte Fassung ${ }^{9}$ dotyczył rozszerzającej mocy obowiązującej niemieckiej ustawy zasadniczej na landy, które pozostawały poza $\mathrm{RFN}^{10}$. Ustanowienie jedności Niemiec nastąpiło na mocy tzw. układu zjednoczeniowego z 31 sierpnia 1990 roku $^{11}$ ratyfikowanego przez parlamenty RFN oraz Niemieckiej Republiki Demokratycznej. Do oficjalnego przyłączenia NRD do Republiki Federalnej Niemiec doszło 3 października 1990 roku. Nie stanowiąc zjednoczenia sensu stricto, połączenie obu państw pozwoliło na przyjęcie przez Niemiecką Republikę Demokratyczną konstytucji RFN.

W miejsce regulacji zawartej w art. 23 a.F. (uchylonego na mocy art. 4 ust. 2 traktatu zjednoczeniowego), wykorzystując zresztą w sposób symboliczny istotę przepisu, wprowadzono nowy cel państwowyw postaci integracji europejskiej. Przywrócenie jedności Niemiec, zawarte jako postulat w art. 23 a.F., zostało zastąpione

${ }^{6}$ Zob. K. Wojtyczek, Zasada otwartej państwowości $w$ Ustawie Zasadniczej RFN, „Przegląd Sejmowy” 2009, nr 6 (95), s. 140.

7 Por. K. Wójtowicz, Otwarcie systemu konstytucyjnego Niemiec na sprawy jedności Europy, „Przegląd Sejmowy” 2009, nr 6 (95), s. 125.

${ }^{8}$ Nowe brzmienie art. $23 \mathrm{uz}$ zostało mu nadane przez Änderungsgesetz (ustawę zmieniająca) z dnia 21 grudnia 1992 r. (BGBl. 1992, t. I, s. 2086).

${ }^{9}$ Pisząc dalej o art. 23 uz posługuję się niemieckimi skrótami: a. F. - alteFassung (stara wersja), n.F. - neueFassung (nowa wersja).

${ }^{10}$ Art. 23 a.F.: „Konstytucja obowiązuje przede wszystkim w landach Badenii, Bawarii, Bremie, Wielkim Berlinie, Hamburgu, Hesji, Dolnej Saksonii, Nadrenii Północnej - Westfalii, Nadrenii - Palatynacie, Szlezwiku - Holsztynie, Badeni-Wirtembergii i Wirtembergii-Hohenzollernie. W innych częściach Niemiec zostanie wprowadzona decyzją o przystąpieniu”.

${ }^{11}$ Układ zjednoczeniowy z dnia 31 sierpnia 1990 r. (BGBl. 1990, t. II, s. 88). 
przez wytyczne w zakresie integracji Niemiec z Unią Europejską. Zjednoczona Europa została określona także jako cel w preambule ustawy zasadniczej. Jednakże, jak słusznie zauważa Krzysztof Wojtyczek, nie określono form prawnych zjednoczenia, w szczególności zabrakło rozstrzygnięcia, czy zjednoczona Europa miałaby być organizacją międzynarodową, ponadnarodową czy też państwem federalnym ${ }^{12}$.

Zarówno art. 23 ust. 1, jak i art. 24 ust. $1 \mathrm{uz}$ nie bez przyczyny odnaleźć można w rozdziale II ustawy zasadniczej zatytułowanym „Federacja i kraje”. W tym przypadku zastosowanie wykładni systemowej podkreśla wyraźnie rangę przepisów przy dokonywaniu podziału kompetencji między Federację i jej landy (nazywane dalej także krajami związkowymi) a Unię Europejską. Konstytucyjna szczegółowość w określaniu relacji między Federacją a krajami związkowym, której przyczyn należy upatrywać w federacyjnej strukturze państwa, jak słusznie zauważa Maria Kruk, przenosi się również na relacje państwo-Unia Europejska ${ }^{13}$.

\section{Przepisy integracyjne w Ustawie zasadniczej Republiki Federalnej Niemiec}

Jak już zostało wskazane wcześniej, w niemieckim systemie konstytucyjnym funkcjonują obecnie dwie klauzule integracyjne. Przepis art. $23 \mathrm{uz}$ stanowi lex specialis w stosunku do art. 24 ust. $1^{14}$. Do roku 1992 wyłącznie art. 24 mógł być jedyną podstawą integracji Niemiec $z$ Unią Europejską, a tym samym - przeniesienia praw zwierzchnich na UE. Obecnie $z$ uregulowania zawartego w art. 24 korzysta się $\mathrm{w}$ zakresie integracji z pozostałymi organizacjami lub organami międzynarodowymi, zaś zbliżanie niemieckiego porządku prawnego $z$ porządkiem prawnym Unii następuje na mocy przepisu art. 23.

12 Zob. K. Wojtyczek, op.cit., s. 139.

13 Zob. M. Kruk, op.cit., s. 44.

${ }^{14}$ H.W. Arndt, K. Fischer, T. Fetzer, Europarecht, 10. Aufl., München 2010, s. 86 . 


\subsection{Klauzula europejska - art. 23 \\ ustawy zasadniczej}

Artykuł 23 składa się $z$ siedmiu ustępów, co czyni go jednym $z$ obszerniejszych przepisów w całej ustawie zasadniczej, będącej uregulowaniem stosunkowo spójnym i zwięzłym. Dla rozważań ujętych w niniejszej pracy interesujący jest jednakże wyłącznie ustęp 1 art. $23^{15}$ i to on będzie stanowić w dalszej części przedmiot deliberacji.

W art. 23 ust. 1 zd. 1 odnajdujemy charakterystykę Unii Europejskiej, uważaną za najobszerniejszą spośród „definicji” UE zawartych w konstytucjach państw członkowskich ${ }^{16}$. Wskazuje się w literaturze, iż przepis art. 23 ust. 1 zd. 1 „Z jednej strony [...] zawiera uznanie, że Niemcy są gotowi współdziałać przy urzeczywistnianiu, z drugiej zaś stawia on [tenże przepis - K.R.] wymagania Unii Europejskiej"17. Obowiązek spełniania wymogów określonych w art. 23 ust. 1 (m.in. ustanowienie gwarancji minimalnej ochrony praw podstawowych, w wielkości co najmniej takiej, jaka jest zawarta w Ustawie zasadniczej RFN) przez Unię Europejską, stanowi warunek członkostwa Niemiec w tej organizacji. Jednocześnie obowiązek ten jest skorelowany $z$ wymogiem konstytucyjnym członkostwa Niemiec w UE jako organizacji realizującej wymogi $z$ art. 23 ust. 1, z której wystąpienie będzie powiązane $z$ naruszeniem przepisów konstytucji ${ }^{18}$.

15 Art. 23 ust. 1 n.F.: „Dla urzeczywistnienia zjednoczonej Europy Republika Federalna Niemiec współdziała w rozwoju Unii Europejskiej, która zobligowana jest zasadami państwowoprawnymi, socjalnymi i federacyjnymi i zasadą subsydiarności oraz gwarantuje porównywalną w zasadzie z niniejszą Ustawą Zasadniczą ochronę praw zasadniczych. Federacja może nadto przekazać ustawą za zgodą Rady Federalnej prawa zwierzchnie. Do umocowania Unii Europejskiej, jak również do zmian jej traktatowych podstaw i porównywalnych uregulowań, w których wyniku niniejsza Ustawa Zasadnicza ulega w swej treści zmianie lub uzupełnieniu albo takie zmiany lub uzupełnienia staną się możliwe, stosuje się artykuł 79 ust. 2 i 3".

${ }_{16}$ Zob. M. Kruk, op.cit., s. 44.

${ }^{17}$ H.W. Arndt, K. Fischer, T. Fetzer, op.cit, s. 86-87.

${ }^{18}$ Zob. K. Wojtyczek, op.cit., s. 145. 
Ustawa zasadnicza w art. 23 rozróżnia dwa tryby przekazania praw suwerennych Unii Europejskiej. Tryb „zwykły” - określony w zd. 2 ust. 1 art. 23 - jest zależny od wyrażenia przez Radę Federalną zgody na przekazanie oraz zachowania formy ustawowej. W niemieckiej tradycji państwowoprawnej niezmiernie istotne jest rozróżnienie między sformułowaniem „w drodze ustawy” (niem. durch Gesetz), zawartym zarówno w art. 23, jak i 24, a wyrażeniem „na podstawie ustawy” (niem. aufgrund Gesetzes). Zgoda Rady Federalnej na przenoszenie praw suwerennych może zostać wyrażona wyłącznie „w drodze ustawy”. Wnioskując a contrario, nie znajdzie tu zastosowania ani rozporządzenie (czyli ustawa w znaczeniu materialnym), ani Landesgesetz (ustawa wydana przez kraj związkowy). Musi zostać zachowana forma Bundesgesetz (ustawy federalnej) ${ }^{19}$.

Drugi $z$ trybów (tzw. kwalifikowany) został określony w art. 23 ust. $1 \mathrm{zd}$. 3. Wskazuje on wyraźnie, że jeśli w zakresie umocowania Unii Europejskiej, zmian jej traktatowych podstaw i porównywalnych uregulowań, będzie niezbędna zmiana lub uzupełnienie ustawy zasadniczej, konieczne będzie zastosowanie art. 79 ust. 2 i 3. Innymi słowy - tryb ten winien zostać zastosowany przy zmianach ustrojowych lub o szczególnym znaczeniu konstytucyjnym ${ }^{20}$. Jak stanowi art. 79 ust. 2 przenosząca prawa zwierzchnie ustawa winna zostać przyjęta za zgodą $2 / 3$ członków Parlamentu Federalnego oraz 2/3 głosów Rady Federalnej. Zgodnie $z$ art. 79 ust. $3^{21} \mathrm{w}$ pewnych sytuacjach nie będzie możliwa w ogóle zmiana konstytucji.

W doktrynie art. 23 ust. 1 zd. 1 określa się jako „kompromisową formułę między $z$ jednej strony otwarciem państwowości RFN i jej UZ na proces integracji, a $z$ drugiej strony ochroną podstawowych

19 Zob. H.D. Jarass, B. Pieroth, Grundgesetz für die Bundesrepublik Deutschland. Kommentar, 9. Aufl., München 2007, s. 564.

${ }^{20}$ Por. K. Wojtyczek, op.cit., s. 145.

${ }^{21}$ Tzw. klauzula wieczności (niem. Ewigkeitsklausel), zawarta w art. 79 ust. 3, nazywana również niekiedy gwarancją wieczności, formułuje zakaz takiej zmiany ustawy zasadniczej, która naruszałaby podział Federacji na kraje, zasadnicze współdziałanie krajów w zakresie ustawodawstwa albo zasady zawarte w artykułach 1 i 20 UZ (m.in. zasada państwa prawnego, demokracji, państwa socjalnego, federacyjnego charakteru państwa). 
zasad strukturalnych RFN i UZ"22. W obecnym stanie prawnym ciężar regulacji pozycji prawnej Niemiec w Unii Europejskiej spoczywa de facto wyłącznie na tymże przepisie.

\subsection{Integrationshebel - uwagi na tle art. 24 ustawy zasadniczej}

Badając regulację zawartą $\mathrm{w}$ przepisie art. $24 \mathrm{uz}$, wskazuje się następujące obszary współpracy międzynarodowej: przekazywanie praw zwierzchnich (zgodnie $\mathrm{z}$ ust. 1, a także $\mathrm{z}$ ust. la w zakresie dotyczącym landów - w sytuacjach, gdy są one uprawnione do wypełniania zadań państwowych), udział w systemach zbiorowego bezpieczeństwa (ust. 2), jak również przystąpienie Federacji do międzynarodowego systemu sądownictwa rozjemczego (ust. 3). W zakresie rozważań zawartych w niniejszej pracy mieści się jedynie ustęp 1 art. $24^{23}$, zaś do pozostałej części przepisu nie będzie konieczne nawiązywanie w dalszej części pracy.

Przepis art. 24 ust. 1 jest regulacją stosunkowo niedookreśloną. Nieokreśloność ta wynika $z$ uniwersalnej formy, w jaką celowo „włożono" ten artykuł - tak by nie preferował żadnej z organizacji międzypaństwowych, do której RFN mogłaby potencjalnie przystąpić. Zgodnie $\mathrm{z}$ tym przepisem „Federacja (der Bund) może w drodze ustawy (durch Gesetz) przenosić prawa suwerenne (Hoheitsrechte) na instytucje międzypaństwowe (zwischenstaatliche Einrichtungen)”. Chcąc więc dokładnie przeanalizować tenże przepis, należy kolejno rozważyć rodzaj otwarcia porządku wewnętrznego, formę prawną przekazania ${ }^{24}$,

22 J. Rutynowski, K. Witkowska-Chrzczonowicz, Polityczne i ustrojowe problemy ratyfikacji Traktatu $z$ Lizbony $w$ RFN - wybrane zagadnienia, „Przegląd Sejmowy” 2011, nr 1 (102), s. 186.

${ }^{23}$ Art. 24 uz: „Federacja może na mocy ustawy przenosić prawa zwierzchnie na jednostki państwowe”.

${ }^{24} \mathrm{~W}$ ustawie, przyjmowanej zwykłą większością głosów, następuje wyrażenie zgody na związanie się Republiki Federalnej Niemiec umową międzynarodową. W zakresie formy prawnej aktualne pozostają uwagi poczynione na tle art. 23 $\mathrm{uz}$ - por. rozważania o różnicy między sformułowaniami durch Gesetz a aufgrund Gesetz w literaturze niemieckiej. 
przedmiot przekazania, podmiot przekazujący oraz podmiot, na rzecz którego prawa są przekazywane ${ }^{25}$.

Przepisy krajów członkowskich Unii Europejskiej przewidują różne sposoby otwierania wewnętrznego porządku prawnego na prawo pochodzące $z$ zewnątrz - może być to przeniesienie praw suwerennych, a także przekazanie kompetencji na rzecz organizacji międzynarodowej czy też delegacja uprawnień władz państwowych. Pojęcie „przekazanie praw zwierzchnich” stanowi „kod dla bardzo złożonego procesu i oznacza zarówno czynność przekazania i przyjęcia, jak i jej rezultat, tj. ponadnarodowy charakter przekazanych praw zwierzchnich"26. Przeniesienie praw w myśl ustaleń art. 24 ust. 1 ogranicza klauzula wieczności - uregulowanie $z$ art. 79 ust. 3, choć nie wynika to bezpośrednio z przepisów ustawy zasadniczej, tak jak w przypadku art. $23^{27}$. Potwierdzenie tego stanowiska można odnaleźć w orzecznictwie FSK, które zostanie szerzej omówione w dalszej części niniejszej pracy.

Prawa suwerenne (Hoheitsrechte), określane w doktrynie niemieckiej jako zbiór uprawnień (kompetencji państwa) w zakresie prawodawstwa, sądownictwa i egzekutywy ${ }^{28}$, stanowią przedmiot przekazania. Definicja praw zwierzchnich obejmuje również kompetencje i zadania państwowe, o których mowa w art. $30 \mathrm{uz}^{29}$.

Podmiotem, który przenosi swoje prawa suwerenne na organizacje międzypaństwowe, jest wyłącznie Federacja, nie zaś kraje

${ }^{25}$ K. Wojtyczek, op.cit., s. 140.

${ }^{26}$ K. Stern, Das Staatsrecht der Bundesrepublik Deutschland, t. 1, München 1984, cyt. za: ibidem, s. 142.

27 Por. D. Hesselberger, Das Grundgesetz. Kommentar für politische Bildung. Sonderausgabe für die Landeszentralen für politische Bildung, 11. Aufl., Neuwid 1999, s. 202.

${ }^{28}$ Zob. uwagi do pojęcia Hoheitsrechte zastosowanego w art. $23 \mathrm{uz}$, aktualne również w stosunku do art. 24: C. Doerfert, Europarecht. Die Grundlagen der Europäischen Union mit ihren politischen und wirtschaftlichen Bezügen, 4. Aufl., München 2010, s. 65; por. B. Schmidt-Bleibtreu, F. Klein, Kommentar zum Grundgesetz, 10. Aufl., München 2004, s.763; A. Kustra, Przepisy i normy integracyjne $w$ konstytucjach wybranych państw członkowskich UE, Torun 2009, s. 106.

${ }^{29}$ Zob. J. Barcz, Między konstytucją a ponadnarodowością: opcja integracyjna konstytucji RFN, Warszawa 1990, s. 90. 
związkowe. Die Bundesländernie otrzymały prawa do cesji swoich uprawnień na Unię Europejską czy każdą inną organizację. Federacja natomiast jest ukonstytuowana do przenoszenia również praw suwerennych przynależnych landom (krajom związkowym) - jedyny wyjątek w tym zakresie został wskazany w art. 24 ust. 1a, zgodnie z którym die Bundesländer mają prawo (po wyrażeniu uprzedniej zgody przez Rząd Federalny) do przekazywania sąsiednim instytucjom przygranicznym pozostających $\mathrm{w}$ ich właściwości uprawnień i zadań państwowych ${ }^{30}$.

Ostatnim z elementów składających się na charakterystykę przepisu art. 24 ust. 1 jest podmiot, na rzecz którego prawa zwierzchnie są przekazywane. W literaturze wskazuje się na pewnego rodzaju cechy konstytutywne pojęcia zwischenstaatliche Einrichtungen (instytucje, niekiedy także tłumaczone jako: organizacje międzypaństwowe). Należą do nich „utworzenie na podstawie umowy międzynarodowej, powstanie w wyniku współdziałania podmiotów prawa międzynarodowego, posiadanie szczególnego charakteru, koniecznego do wykonywania przekazanych na jej [organizacji międzynarodowej - K.R.] rzecz praw zwierzchnich" ${ }^{31}$. Mając na uwadze fakt, iż organizacje międzynarodowe są co do zasady zbudowane na zasadzie członkowskiej (bądź stowarzyszeniowej), należy przyjąć, iż RFN powinna przynależeć do tejże instytucji, zwłaszcza że następuje przekazanie na jej rzecz praw suwerennych Republiki. Ponadto mimo elastyczności terminu „instytucja międzypaństwowa”, należy zgodzić się z Aleksandrą Kustrą, która wskazuje na konieczność ograniczenia zakresu zastosowania przepisu art. 24 wyłącznie do organizacji ponadnarodowych. „Tylko bowiem organizacje supranacjonalne charakteryzuje możliwość wykonywania praw suwerennych, przekazanych im na mocy traktatu międzynarodowego przez państwa członkowskie"32.

${ }^{30}$ Zob. B. Schmidt-Bleibtreu, F. Klein, op.cit., s. 763.

${ }^{31}$ A. Bleckmmann, Grundgesetz und Völkerrecht, Berlin 1975, s. 229, cyt. za: A. Kustra, op.cit., s. 103.

${ }^{32}$ A. Kustra, op.cit., s. 105. 


\section{Kształtowanie pojęcia Verfassungsidentität w orzecznictwie Federalnego Sądu Konstytucyjnego}

Państwa członkowskie Unii Europejskiej z różną siłą chronią swoją suwerenność (tożsamość). Pojęcie to definiowane jest w literaturze przez wskazanie jej pozytywnej (zdolność do podejmowania działań i decydowania w zakresie spraw wewnętrznych i międzynarodowych) i negatywnej strony (przedstawianej jako prawna niezależność od czynników zewnętrznych) ${ }^{33}$. Bywa, że suwerenność określa się jako „kompetencję do przyznania kompetencji, a także możliwość uchylenia wszelkich kompetencji przez podmiot sprawujący władzę"34. Wraz z przeniesieniem praw suwerennych państwo otwiera swój krajowy system prawny, co oznacza rezygnację $\mathrm{z}$ pewnego rodzaju osłony. Konsekwencją tego jest „wkroczenie” ponadnarodowego prawa Unii Europejskiej bezpośrednio w zakres wewnętrznego prawa krajowego oraz nadanie mu pierwszeństwa przed prawem krajowym ${ }^{35}$.

Zgodność traktatu z Lizbony z narodowymi konstytucjami państw członkowskich Unii jest przedmiotem wielu wyroków narodowych sądów i trybunałów konstytucyjnych. W orzecznictwie ukształtowały się dwa podejścia do przedmiotowej kwestii - akceptacja przekazania kompetencji $z$ ogólnym zastrzeżeniem granic przekazania (metoda zastosowana m.in. przez Sąd Konstytucyjny Republiki Czeskiej) oraz wskazanie materialnych granic przeniesienia uprawnień i zdefiniowanie istoty suwerenności (tożsamości) narodowej (tak orzekały m.in. francuska Rada Konstytucyjna i niemiecki FSK). Jak wskazuje Krzysztof Wójtowicz, sposób francuski i niemiecki, choć

${ }^{33}$ Zob. M. Tuchowska, Suwerenność - pojęcie oraz ewolucja idei $w$ oparciu o akty ustrojowe państw europejskich, w: Konstytucyjnoprawne i polityczne aspekty członkostwa w Unii Europejskiej, red. A. Kustra, Torun 2009, s. 93.

34 J. Galster, Zasada przychylności wobec prawa międzynarodowego Ustawy Zasadniczej Republiki Federalnej Niemiec, Toruń 1995, s. 125.

${ }^{35}$ R. Arnold, Orzecznictwo niemieckiego Federalnego Trybunału Konstytucyjnego a proces integracji europejskiej, „Studia Europejskie” 1999, nr 1, s. 96. 
nie jest tak otwarty na integrację, „wydaje się w większym stopniu spełniać wymogi zasady pewności prawa, gdyż czyni bardziej przewidywalnym wynik rozstrzygnięcia ewentualnych przyszłych kolizji prawa krajowego i prawa Unii” ${ }^{36}$.

W celu rozważenia kwestii suwerenności Republiki Federalnej Niemiec oraz tożsamości konstytucyjnej tego państwa nie sposób nie odnieść się do kluczowego wyroku $\mathrm{FSK}^{37}$ z 30 czerwca 2009 roku w sprawie zgodności Traktatu o Unii Europejskiej oraz Traktatu o funkcjonowaniu Unii Europejskiej w wersji przyjętej w traktacie z Lizbony, jak również dwóch innych ustaw ${ }^{38}$ z Ustawą zasadniczą RFN.

Federalny Sąd Konstytucyjny wskazał na wiele niezmiernie istotnych elementów dotyczących tożsamości narodowej i władzy konstytucyjnej, nie tylko niemieckiej, ale również innych państw członkowskich. Zgodnie z tezą 234 Lissabon - Urteil, nawiązującą do tezy 235, „zasada prawa europejskiego dotycząca ograniczonych przyznanych kompetencji oraz europejski obowiązek dotyczący poszanowania tożsamości stanowią traktatowy wyraz państwowo-konstytucyjnoprawnych podstaw władzy unijnej”. Federalny Sąd Konstytucyjny zaznaczył także, że w ramach swoich uprawnień będzie badać, czy stanowiący konstytucyjną podstawę tożsamości narodowej art. 79 ust. $3 u z^{39}$ nie został naruszony. Klauzula

${ }^{36}$ K. Wójtowicz, Poszanowanie tożsamości konstytucyjnej państw członkowskich Unii Europejskiej, „Przegląd Sejmowy” 2010, nr 4 (99), s. 16.

37 Wyrok Federalnego Sądu Konstytucyjnego z dnia 30 czerwca 2009 r., 2BvE2/08, BVerfG (orzecznictwo Federalnego Sądu Konstytucyjnego), http:// www.bverfg.de/entscheidungen/es20090630_2bve000208.html, (dostęp: 1 sierpnia 2013 r.); dalej: Lissabon - Urteil.

${ }^{38}$ Tzw. ustawy towarzyszące (Begleitgesetze), obie przyjęte (wraz z ustawą ratyfikującą traktat z Lizbony) 24 kwietnia 2008 roku przez Bundestag i zaakceptowane przez Bundesrat, a mianowicie Ustawa o zmianie Ustawy zasadniczej (das Gesetzzur Änderung des Grundgesetzes) z dnia 8 października 2008 r., (BGBl. 2008, t. I, s. 1926) oraz ustawa w sprawie rozszerzenia i wzmocnienia uprawnień Bundestagu i Bundesratu w sprawach Unii Europejskiej (das Gesetzüberdie Ausweitungund Stärkung der Rechte des Bundestagesund Bundesrates in Angelegenheiten der Europäischen Union), BTDrucks 16/8489.

${ }^{39}$ Zob. przyp. 27. FSK w wyroku z 30 czerwca 2009 roku (teza 235) wskazał również, iż klauzula wieczności „stanowi odpowiednik obowiązku z prawa 
wieczności, stanowiąca istotę art. 79 ust. 3, wyznacza granice przyszłego politycznego rozwoju RFN, jest wyrażeniem niemieckiej nieprzenaszalnej tożsamości konstytucyjnej (niem. unverfügbare Verfassungsidentität), odpornej na działania integracyjne ${ }^{40}$ oraz „jądrem” tożsamości narodowej RFN, w związku z czym nie powinna w żadnym przypadku podlegać przekazaniu. Co istotne, to stanowisko niemieckiego Sądu nie zmienia się od wielu lat ${ }^{41}$. Przykładowo w sprawie Solange I FSK wskazywał na istnienie takich elementów niemieckiego prawa konstytucyjnego, które nie mogą podlegać relatywizacji przez prawo wspólnotowe (unijne) ${ }^{42}$. Jednocześnie należy podkreślić, iż nienaruszalność art. 79 ust. 33 dotyczy nie tylko zmian formalnych, ale również materialnych, które mogłyby zostać wywołane przez przeniesienie uprawnień państwa na Unię Europejską. Przepis art. $24 \mathrm{w}$ zakresie, w jakim upoważnia do przekazania praw suwerennych na instytucje międzynarodowe, nie stanowi jednocześnie umożliwienia zmiany konstrukcji porządku konstytucyjnego - nie może to nastąpić bez przyjęcia zmian w konstytucji ${ }^{43}$.

Wyrok w sprawie Solange II był swoistego rodzaju zapewnieniem FSK wystosowanym w kierunku Unii Europejskiej. Tak długo, jak ówczesne Wspólnoty Europejskie gwarantują ochronę praw zasadniczych równą co najmniej poziomowi ochrony ustalonemu w ustawie zasadniczej Niemiec, FSK nie podejmie się badania zgodności przepisów wspólnotowych (unijnych) z konstytucyjnymi prawami podsta-

europejskiego do poszanowania władzy konstytucyjnej Państw Członkowskich jako panów traktatów".

40 Por. Lissabon - Urteil, teza 235.

${ }^{41}$ FSK orzekał w ten sposób wcześniej: wyrok FSK z 29 maja 1974 r., BvL 52/7, BVerfGE, t. 37, s. 271 i nast., dalej: Solange I; wyrok FSK z 22 października 1986 r., 2 BvR 197/83, BVerfGE, t. 73, s. 339 i nast., dalej: Solange II; wyrok FSK z 12 października 1993 r., 2 BvR 2134, 2159/92, BVerfGE, t. 89, s. 155 i nast. (wyrok w sprawie traktatu $z$ Maastricht).

42 Por. R. Arnold, op.cit., s. 99.

43 Zob. B. Banaszkiewicz, P. Bogdanowicz, Relacje między prawem konstytucyjnym a prawem wspólnotowym $w$ orzecznictwie sądów konstytucyjnych państw Unii Europejskiej, Warszawa 2006, s. 68; http://www.trybunal.gov.pl/ epublikacje/download/EUROPA_2006.pdf (dostęp: 14 sierpnia 2013 r.). 
wowymi RFN. Natomiast w wyroku w sprawie traktatu z Maastricht Sąd wywodził, iż Unia Europejska nie dąży do wykreowania nowej własnej państwowości. Będąc związkiem państw, działa w ramach ograniczonych kompetencji, powierzonych jej przez państwa członkowskie ${ }^{44}$, nie posiada bowiem kompetencji do określania własnych kompetencji (Kompetenz - Kompetenz). Jednocześnie FSK odniósł się do wydawania aktów unijnych $z$ przekroczeniem zasady kompetencji powierzonych (aktów ultra vires), uznając je za nieskuteczne.

Instytucje unijne działają zgodnie $z$ wyartykułowaną w przepisie art. 5 Traktatu o Unii Europejskiej ${ }^{45}$ (dalej: TUE) zasadą przyznania - Unia dysponuje wyłącznie uprawnieniami, które państwa członkowskie przyznały jej w traktatach. $Z$ art. 4 ust. 1 TUE wynika zaś domniemanie kompetencji na rzecz państw członkowskich. Artykuł 23 ust. 1 uz w kontekście zasady kompetencji powierzonych (czy też zasady przyznania) będzie stanowił natomiast hamulec dla unijnych dążeń do głębszej jedności, tworzenia europejskiego państwa federalnego czy też innych form zbliżania krajów członkowskich. Na mocy tych postanowień należy uznać, iż art. 23 ust. $1 \mathrm{uz}$ nie stanowi konstytucyjnej podstawy do nieograniczonego udziału Republiki Federalnej Niemiec w Unii Europejskiej ${ }^{46}$.

Federalny Sąd Konstytucyjny w wyroku w sprawie traktatu z Lizbony szczególnie podkreślił swoją pozycję w systemie kontroli konstytucyjności aktów unijnych. Kompetencję do orzekania o niestosowaniu aktu UE przyznał sobie w szczególności w stosunku do aktów umocowanych bez obowiązkowego ustawowego upoważnienia, jak również do sytuacji naruszenia tożsamości konstytucyjnej,

${ }^{44}$ FSK potwierdził tę tezę w wyroku z 30 czerwca 2009 roku w sprawie traktatu z Lizbony; zob. B. Banaszkiewicz, P. Bogdanowicz, op.cit., s. 79; S. Pawłowski, Zjednoczeni $w$ różnorodności - perspektywa niemieckiego Federalnego Trybunału Konstytucyjnego, w: Konferencja „Unia Europejska: zjednoczeni w różnorodności" Warszawa, 14-15 grudnia 2010 r., red. C. Mik, Warszawa 2011 , s. 153, http://orka.sejm.gov.pl/WydBAS.nsf/0/9EF3B748DCCC8B93C1257B2E003ECF19/\$file/Zjednoczeni_w_roznorodnosci.pdf (dostęp: 17 listopada 2013 r.).

45 Traktat o Unii Europejskiej, wersja skonsolidowana, Dz.Urz. UE C 83 z 30 marca 2010 r.

${ }^{46}$ Zob. J. Rutynowski, K. Witkowska-Chrzczonowicz, op.cit., s. 187. 
zasady pierwszeństwa czy zasady kompetencji powierzonych ${ }^{47}$. Uważa się jednak w literaturze, iż nowe sprawdziany konstytucyjności nie powinny utrudniać zapewnienia efektywności stosowania prawa unijnego w Niemczech ${ }^{48}$.

Lissabon - Urteil w pewnych kwestiach ma charakter edukacyjny - zostały dookreślone reformy wprowadzone traktatem $z$ Lizbony. Unia Europejska przekształciła się bowiem na mocy tegoż traktatu w jednolitą organizację międzynarodową, tworzoną przez kraje członkowskie, które jednakże zachowują pełną suwerenność (państwa pozostają panami traktatów - niem. Herren der Verträge). Wtórnego charakteru uprawnień nie zmienia nadanie Unii podmiotowości prawnej - nadal muszą one mieścić się w zakresie kompetencji powierzonych. Tożsamość konstytucyjna państw członkowskich wyznacza granicę dozwolonych działań $\mathrm{UE}^{49}$, a także zakres procesu dalszej integracji. Istotne jest przy tym jest zachowanie precyzyjności w określaniu kompetencji organów unijnych z jednoczesną eliminacją procesu przekazania tymże organom kompetencji do decydowania o własnych kompetencjach (Kompetenz - Kompetenz ${ }^{50}$. Wyrok miał w dużej mierze pozytywny oddźwięk w piśmiennictwie. Gero Kellermann określił go wręcz jako „wygnanie mgły znad europejskich gór”, zaznaczając, że dzięki niemu została osiągnięta klarowność co do państwowo-prawnego charakteru $\mathrm{UE}^{51}$.

47 Por. T. Silberhorn, Zur Rolle des deutschen Bundestages nach dem Lissabon-Urteil des Bundesverfassungsgerichts, w: Europäische Integration und deutsche Verfassungsidentität, 5. Berliner rechtspolitische Konferenz, Hrsg. R. T. Baus, M. Borchard, G. Krings, Sankt Augustin-Berlin 2010, s. 140.

${ }^{48}$ Zob. J. Barcz, Niemcy: wyrok Federalnego Trybunału Konstytucyjnego z dnia 30 czerwca 2009 r. w sprawie ratyfikacji Traktatu z Lizbony, „Przegląd Sejmowy" 2009, nr 6 (95), s. 258.

49 Ibidem, s. 257.

50 Zob. P. Bała, „Tożsamość konstytucyjna” a traktat z Lizbony. Tezy wyroku Federalnego Trybunału Konstytucyjnego z 30 czerwca 2009 r., „Ius Novum” 2010, nr 2, s. 21.

51 Zob. G. Kellermann, Integrationsverantwortung und Verfassungsidentität - Das Urteil des Bundesverfassungsgerichts zum Vertrag von Lissabon, „Akademie - Kurzanalyse” 2009, nr 1, s. 5. 


\section{Uwagi końcowe}

Nie jest łatwą i jednoznaczną ocena „odpowiedniości” opcji integracyjnej Republiki Federalnej Niemiec. Od momentu powstania Unii kraj ten uczestniczy w jej strukturach, w związku z czym przepisy niemieckiej ustawy zasadniczej, co oczywiste, na przestrzeni ostatnich 60 lat mogły zmienić się (i zmieniały) wielokrotnie, w tym również w zakresie tzw. artykułu europejskiego. Zakładając, iż na chwilę obecną integracja Niemiec z UE jest maksymalnie pogłębiona, obecna regulacja wydaje się wystarczająca i odpowiednia. Istnieje grupa krytyków art. 23 uz, którzy szeroką i wyczerpującą regulację tego artykułu uważają za błędną, niepotrzebną i zbyt daleko idącą. Moim zdaniem nie należy w swych poglądach stawiać zbyt radykalnych tez - zarówno na korzyść, jak i niekorzyść art. 23.

Podsumowując orzecznictwo FSK w zakresie tożsamości konstytucyjnej Niemiec, należy stwierdzić, że od początku orzekania FSK stabilnie i niezmiennie stoi na straży suwerenności państwa. Ta stabilność orzecznictwa FSK tkwi z pewnością w głęboko zakorzenionym federalizmie, a także warunkowana jest trudną historią Niemiec. Federalny Sąd Konstytucyjny nie jest uległy wobec zasad określonych w art. 79 ust. 3 uz, zaś w szczególności chroni art. 1 i 20 - trudno jednak czynić z tego zarzut, jeśli zna się niemiecką historię i pamięta deficyty demokracji, który ten kraj przeżywał. $Z$ tego też względu należy krytycznie podchodzić do wyroków FSK, zaś ich słuszność uzależniać każdorazowo od sytuacji, w jakiej zostanie dane orzeczenie przywołane.

Choć nie jest to bezpośrednio przedmiotem niniejszej pracy, nie sposób nie wspomnieć również o wpływie, jaki orzecznictwo FSK wywiera na pozostałe kraje Unii, w tym również Polskę. Wyroki Sądu, choć nie wiążą w żaden sposób polskich władz, stanowią pewną formę sugestii, politycznej inspiracji, co w szczególności uwidoczniło się w wyroku Drugiego Senatu FTK w sprawie traktatu lizbońskiego z 30 czerwca 2009 roku. Federalny Sąd Konstytucyjny w swym wyroku zauważył, iż w wyniku reformy wprowadzonej traktatem z Lizbony nastąpi nie tylko przekształcenie Unii Europejskiej w jednolitą organizację międzynarodową, lecz również będzie 
ona początkiem wzmocnienia pozycji parlamentów narodowych, co prawdopodobnie będzie prowadzić również do konieczności podniesienia skuteczności polskiego Sejmu i Senatu w działaniach związanych z Unią.

\section{STRESZCZENIE}

Przepisy i normy otwierające porządek prawny na prawo międzynarodowe i procesy integracyjne w Republice Federalnej

Niemiec

Tematem referatu są normy otwierające porządek prawny na prawo międzynarodowe i procesy integracyjne w Ustawie zasadniczej Republiki Federalnej Niemiec. W niemieckim piśmiennictwie dominują dwie nazwy: artykuł europejski (niem. Europa-Artikel) oraz dźwignia integracyjna (niem. Integrationshebel). Przepisy przenoszące prawa suwerenne Republiki Federalnej Niemiec na organizacje międzynarodowe i Unię Europejską, stanowią stosunkowo odmienną (na tle pozostałych krajów Unii) regulację. Charakterystyka art. 23 ust. 1 i art. 24 ust. 1 uz wyjaśnia treści tych przepisów. Regulacje, choć w istocie podobne, dotyczą jednak innych podmiotów - adresatów hipotez zawartych w powyższych artykułach. Sformułowanie „dźwignia integracyjna” jest spotykane zdecydowanie rzadziej, co może być spowodowane utratą znaczenia art. 24, kryjącego się pod tym określeniem. Pojęcie Europa-Artikel dotyczy członkostwa Republiki Federalnej Niemiec w Unii Europejskiej (Wspólnotach Europejskich). Niemcy współtworzyli Unię Europejską, zaś członkostwo w tejże organizacji miało głęboki wpływ na zmiany zachodzące w przepisach niemieckiej konstytucji, w tym w zakresie tzw. artykułu europejskiego. Przy założeniu, iż integracja RFN z UE jest już maksymalnie pogłębiona, obecna regulacja wydaje się wystarczająca i odpowiednia. Istnieją co prawda krytycy art. 23, którzy regulację uważają za bezużyteczną i zbyt daleko idącą. W wyroku II Senatu FSK w sprawie traktatu lizbońskiego z 30 czerwca 2009 roku. FSK zauważył, iż, w wyniku reformy wprowadzonej traktatem z Lizbony, nastąpi nie tylko przekształcenie Unii Europejskiej w jednolitą organizację międzynarodową, lecz również będzie ona początkiem wzmocnienia pozycji parlamentów narodowych.

Słowa kluczowe: przepisy przekazujące prawa suwerenne, art. 23 i 24 Ustawy zasadniczej Republiki Federalnej Niemiec, klauzula europejska, 
Unia Europejska, tożsamość konstytucyjna (Verfassungsidentität), Federalny Sąd Konstytucyjny (Bundesverfassungsgericht), traktat z Lizbony.

\section{SUMMARY}

Rules and regulations opening the legal system for the international law and the processes of integration in the Federal Republic of Germany

The subject of a paper are regulations, which open the legal order for the international law and the processes of integration in the Basic Law of the Federal Republic of Germany. Two names have the dominant position in the german literature: "European Article" (German: Europa-Artikel) and „integrated leverage” (German Integrationshebel). The sovereign rights of the Federal Republic of Germany, which are transferred by the regulations to international organizations and the European Union, are relatively different (in comparison to other EU countries) regulation. Profiles of Articles 23.1 and 24.1 of the Basic Law explain the essence of these regulations. Although in fact the regulations are similar, they concern different subjects - the addressees of hypotheses contained in the articles, which are mentioned above. The term ,integrated leverage” is used rarely because article 24 - Intergationshebel - lost its meaning. The term EuropaArtikela pplies to the Federal Republic of Germany's membership in the European Union (European Community). The Federal Republic of Germany co-created the European Union. The status of a European Union Member State had a profound influence on the changes in the regulations of the Basic Law, including the "European Article". Assuming that the integration Federal Republic of Germany with the EU is already very developed, the current regulation seems to be sufficient and relevant. There are critics of Article 23, who think that the regulation is useless and that it reaches too far. In the judgment of the Second Senate of the Federal Constitutional Court of 30 June 2009 - the Treaty of Lisbon's case, the Federal Constitutional Court noticed that, as a result of reforms which were introduced in the Treaty of Lisbon, the European Union may be transform into an unified international organization and also these reforms may reinforce the position of national parliaments.

Keywords: transfer of sovereign powers, Article 23 and 24 of Basic Law for the Federal Republic of Germany, a European clause, European Union, 
constitutional identity (Verfassungsidentität), the Federal Constitutional Court (Bundesverfassungsgericht), the Treaty of Lisbon.

\section{BIBLIOGRAFIA}

Arndt H.W., Fischer K., Fetzer T., Europarecht, 10. Aufl., München 2010. Arnold R., Orzecznictwo niemieckiego Federalnego Trybunału Konstytucyjnego a proces integracji europejskiej, „Studia Europejskie” 1999, nr 1.

Bała P., „Tożsamość konstytucyjna” a traktat z Lizbony. Tezy wyroku Federalnego Trybunału Konstytucyjnego z 30 czerwca 2009 r., „Ius Novum” 2010, nr 2.

Banaszkiewicz B., Bogdanowicz P., Relacje między prawem konstytucyjnym a prawem wspólnotowym $w$ orzecznictwie sąów konstytucyjnych państw Unii Europejskiej, Warszawa 2006, http://www.trybunal.gov.pl/epublikacje/download/EUROPA_2006.pdf (dostęp: 14 sierpnia 2013 r.).

Barcz J., Między konstytucją a ponadnarodowością: opcja integracyjna konstytucji RFN, Warszawa 1990.

Barcz J., Niemcy: wyrok Federalnego Trybunału Konstytucyjnego z dnia 30 czerwca 2009 r. $w$ sprawie ratyfikacji Traktatu z Lizbony, „Przegląd Sejmowy" 2009, nr 6 (95).

Bleckmmann A., Grundgesetz und Völkerrecht, Berlin 1975.

Doerfert C., Europarecht. Die Grundlagen der Europäischen Union mit ihren politischen und wirtschaftlichen Bezügen, 4. Aufl., München 2010.

Galster J., Zasada przychylności wobec prawa międzynarodowego Ustawy Zasadniczej Republiki Federalnej Niemiec, Torun 1995.

Hesselberger D., Das Grundgesetz. Kommentar für politische Bildung. Sonderausgabe für die Landeszentralen für politische Bildung, 11. Aufl., Neuwid 1999.

Jarass H.D., Pieroth B., Grundgesetz für die Bundesrepublik Deutschland. Kommentar, 9. Aufl., München 2007.

Kellermann G., Integrationsverantwortung und Verfassungsidentität - Das Urteil des Bundesverfassungsgerichts zum Vertrag von Lissabon, „Akademie - Kurzanalyse" 2009, Nr. 1.

Kruk M., Kształtowanie konstytucyjnych zasad członkostwa państwa w Unii Europejskiej (wybrane problemy), „Przegląd Sejmowy” 2010, nr 4 (99).

Kustra A., Przepisy i normy integracyjne $w$ konstytucjach wybranych państw członkowskich UE, Toruń 2009.

Pawłowski S., Zjednoczeni $w$ różnorodności-perspektywa niemieckiego Federalnego Trybunału Konstytucyjnego, w: Konferencja „Unia Europejska: zjednoczeni $w$ różnorodności" Warszawa, 14-15 grudnia 2010 r., red. C. Mik, Warszawa 2011, http://orka.sejm.gov.pl/WydBAS.nsf/0/9E- 
F3B748DCCC8B93C1257B2E003ECF19/\$file/Zjednoczeni_w_roznorodnosci.pdf (dostęp: 17 listopada 2013 r.).

Rutynowski J., Witkowska-Chrzczonowicz K., Polityczne i ustrojowe problemy ratyfikacji Traktatu $z$ Lizbony $w$ RFN - wybrane zagadnienia, „Przegląd Sejmowy” 2011, nr 1 (102).

Schmidt-Bleibtreu B., Klein F., Kommentar zum Grundgesetz, 10. Aufl., München 2004.

Silberhorn T., Zur Rolle des deutschen Bundestages nach dem Lissabon-Urteil des Bundesverfassungsgerichts, w: Europäische Integration und deutsche Verfassungsidentität, 5. Berliner rechtspolitische Konferenz, Hrsg. R.T. Baus, M. Borchard, G. Krings, Sankt Augustin-Berlin 2010.

Starck Ch., Ustawa Zasadnicza po 60 latach. Niemieckie i europejskie perspektywy, „Przegląd Sejmowy” 2009, nr 6 (95).

Tuchowska M., Suwerenność - pojęcie oraz ewolucja idei, w oparciu o akty ustrojowe państw europejskich, w: Konstytucyjnoprawne i polityczne aspekty członkostwa w Unii Europejskiej, red. A. Kustra, Torun 2009.

Wojtyczek K., Zasada otwartej państwowości w Ustawie Zasadniczej RFN, „Przegląd Sejmowy” 2009, nr 6 (95).

Wójtowicz K., Otwarcie systemu konstytucyjnego Niemiec na sprawy jedności Europy, „Przegląd Sejmowy” 2009, nr 6 (95).

Wójtowicz K., Poszanowanie tożsamości konstytucyjnej państw członkowskich Unii Europejskiej, „Przegląd Sejmowy” 2010, nr 4 (99). 
